\title{
Quantitative assessment of material composition of end-of-life ships using onboard documentation
}

\author{
K.P. Jain*, J.F.J. Pruyn^, J.J. Hopman\# \\ Department of Maritime and Transport Technology, Faculty of 3mE, Delft University of Technology, \\ Mekelweg 2, 2628CD, Delft, The Netherlands \\ *k.p.jain@tudelft.nl, ^ j.f.j.pruyn@tudelft.nl, \# j.j.hopman@tudelft.nl \\ doi:10.1016/j.resconrec.2015.11.017 \\ URL (open till 11.02.2016): http://authors.elsevier.com/a/1SFiU3HVLKP6HC
}

\begin{abstract}
:
Ship recycling yards around the world offer a price to the ship owners for buying an obsolete vessel to demolish and recycle based on the ship's end-of-life weight. The offer price is mainly based on the type of ship and the estimated quantity of steel available. The steel weight estimation, in terms of percentage of lightweight (LDT), is carried out either on the basis of recycling yards' experience or by an expert opinion without using any scientifically rigorous method. The accurate quantification of all the material streams of an end-of-life ship is needed for planning the ship recycling process with better resource allocation and waste management strategies, especially in light of the Hong Kong convention and the new EU regulation on ship recycling. It might also assist in better estimation of cost and income of recycling the ship. A literature survey of the subject found that a clear knowledge gap exists in this area of study, only aggregate data of materials of ships is available, no ship by ship data exist. Thus, in this paper, a methodology to quantify material streams of an individual ship using the information readily available at the end of its life is presented. The advantages of using the developed methodology are explained. Lastly, a few recommendations to improve future ship designs for safe and environmentally sound ship recycling are presented based on the knowledge gained in the methodology development process.
\end{abstract}

\section{Keywords:}

End-of-life ships; ship recycling; material quantification; ship scrap; waste management; design for recycling

\section{Introduction}

Ship owners sell their end-of-life (EOL) ships to ship recycling yards either directly or through a cash buyer or broker. In some cases, even two brokers each representing the ship owner and the ship recycling yard and a cash buyer can be involved. The amount of money a ship owner gets for selling an EOL ship is determined by negotiation and depends on various factors - global, local and others.

Globally, the offer price is regulated by the ship demolition market depending on the supply of obsolete ships and demand for scrap metal. The supply of obsolete ships is increased during economic downturn when the demand for ships for maritime transportation is reduced, while an increased demand for scrap steel increases the demand for obsolete ships (Stopford, 2009, Sarraf, 2010). This is due to the fact that the major portion (60\% to $80 \%$ ) of the weight of a ship is steel (Bertram and Schneekluth, 1998). The high supply of obsolete ships in the demolition market coupled with a low demand for scrap steel lowers the offer price while a low supply of ships during a high demand for scrap steel results in a higher offer price.

Locally, factors such as health, safety and environmental standards, intended purpose of demand for scrap steel (melting or re-rolling), local demand for other recyclable items (non-ferrous scrap, used machinery, furniture etc.), labour wages and recycling method employed (beaching, slipway, alongside, drydock) plays an important role in determining the price of an EOL ship (Sarraf, 2010). For example, higher prices offered by sub-continent recycling yards as compared to those in China and 
Turkey is partially attributed to the availability of downstream markets formed by industrial agglomeration of 'second-hand' shops and re-manufacturing/re-processing/re-furbishing firms buying almost everything including ship's machinery, motors, furniture, tanks, hardware, ancillary fittings etc. (Hiremath et al., 2015, Rahman and Mayer, 2015, Gregson et al., 2012, Crang et al., 2013) helping recyclers realise value from otherwise 'waste' materials of the ship. The ship recycling yards in major ship recycling nations such as India, Bangladesh, China, Pakistan and Turkey offer different prices due to such factors.

Other factors affecting the offer price include geographical position of the ship and the distance to the recycling yard, deal terms such as 'on delivery' and 'as-is, where-is', hull configuration in terms of complexity, ship's compatibility with yard's specifications in terms of size and draft restrictions, and items remaining on board such as bunkers, waste oil etc.

In most cases, ship recycling yard offers a price to a ship owner on the basis of rough estimations of the amount of steel available on an EOL ship. The ship recycling yards make estimates on the basis of either experience or by an expert opinion without using any scientifically rigorous method (Misra and Mukherjee, 2009). Moreover, they do not take into account the amount of other material streams such as non-ferrous metals, machinery, hazardous materials, liquids, chemicals, gases etc. in determining the offer price.

The offer price should actually be determined on the basis of the estimation of cost and revenue generated in dismantling and recycling a ship. Although there are many factors affecting the cost and revenue of recycling a ship, type and quantity of materials plays an important role. For example, high quantity of asbestos will result in extra measures to be taken and a longer processing time resulting in higher cost for recyclers. Also, the revenue is mainly generated by selling materials such as ferrous scrap, non-ferrous scrap, machinery, equipment and other items. The material quantification of a ship is thus essential for planning the recycling yard's operations and will help recyclers incorporate the effect of materials on the price offered to a ship owner.

The quantified material streams are essential for yards to create a robust ship recycling plan as required by not yet applicable EU regulation and Hong Kong convention on ship recycling. An enhanced ship recycling plan can be devised because the quantified material streams can be used to determine the amount of waste that would be generated in recycling an EOL ship depending upon the earning potential of each of the material streams as well as to carry out a material flow analysis (MFA). MFA, an analytical method of systematic assessment of flows of materials within a complex system defined in space and time (Brunner and Rechberger, 2004), is a tested technique which was applied in the past on specific EOL products that are potential sources of materials including EOL commercial vehicles (Mathieux and Brissaud, 2010) and short life goods such as aluminium packaging and glass (Binder and Mosler, 2007). The concept of MFA can also be applied for better waste management (Arena and Di Gregorio, 2014, Brunner and Rechberger, 2004) and sustainable development (Huang et al., 2012).

MFA has never been applied on ships except being mentioned by Sujauddin et al. (2014) pointing to another publication of theirs (Sujauddin et al., 2012) stating this area of study remained unexplored. If MFA is applied on a ship recycling yard, it can help reduce recycling costs, improve hazardous waste management and enhance environmental performance by optimizing the recycling process in such a way that resources are allocated and utilized in the most efficient manner. MFA can help carefully plan the steps to reduce a several hundred meters long ship to small pieces suitable for re-melting furnaces by optimizing the number and size of the pieces that can be cut from a ship, the number and capacity of cranes and forklifts available to move them off the ship to processing stations elsewhere in the yard, the capacity of the processing stations to cut up and sort the metals, and the capacity of the truck loading systems so that the materials flow smoothly through the process with minimum labour and without delays. Precisely, MFA based on the quantified material streams can be used as a tool to better plan the ship recycling process for achieving cost effective, safe and environmentally sound ship recycling. 
This paper will continue further with a review of the limited literature available on the estimation of materials of the ships to be recycled. It will also briefly search for inspiration in other industries, such as vehicle and aircraft sectors. Although useful, the impact of best practices from other industries will only benefit ship recycling in 20-30 years' time (lifetime of vessels), hence the paper will also develop a method that will use the official and thus obligatory vessel documentation to more accurately estimate the different material weights of the vessel.

\section{Literature review}

\subsection{Comparison with other industries}

It would be worthwhile to discuss why is it important to develop a methodology for material quantification of EOL ships by comparing the ship recycling industry with the aircraft and the vehicle recycling industry.

The recycling approach of the shipping industry resembles the approach used by the aircraft recycling industry. The aircraft recycling involves disassembly of reusable components and then shredding the remaining hull to obtain ferrous and non-ferrous scrap using the separation technologies (van Heerden and Curran, 2010). Similarly, the ship recycling industry is pre-dominantly based on salvaging as many components as possible having second-hand value in the market and then cutting the ship's hull (ferrous) into plates and blocks of sizes that are readily accepted in the scrap market (Andersen et al., 2001). On the contrary, the vehicle recycling industry mainly rely on shredding the vehicle hull to obtain ferrous and non-ferrous scrap for recycling using the separation technologies because of nonexistent market of reusable components (Sakai et al., 2014). Moreover, vehicle recycling industry has frequent supply of small units unlike the ship recycling industry having an intermittent supply of large units.

Though, the ship recycling industry resembles the aircraft recycling industry in following a similar recycling approach; its earning model is similar to that of the vehicle recycling industry, contrary to the earning model used by the aircraft recycling industry. It depends more on scrap value than on component value (van Heerden and Curran, 2010). This is the reason why material quantification related studies are abundantly available within the literature of vehicle recycling industry (Ferrão et al., 2006, Gerrard and Kandlikar, 2007, Jeff and Gregory, 2001, Kanari et al., 2003, Mat Saman and Blount, 2006, Vermeulen et al., 2011) while the literature of aircraft recycling industry is more focused on disassembly of reusable components (De Brito et al., 2007, Ribeiro and Gomes, 2015, van Heerden and Curran, 2010).

In conclusion, ship recycling industry is similar to both vehicle and aircraft recycling industry in certain aspects; yet the difference not only due to large size and various types of ships but also due to large age range, infrequent supply and dynamic composition of ships due to change in regulations over time makes it difficult to instantly apply the existing quantification models of other industries. The strong market presence for EOL ship's machinery, equipment and other reusable items is similar to that of aircraft recycling while high demand for high value non-ferrous scrap such as special bronze and ferrous scrap in the form of plates and blocks in the scrap market is similar to that of vehicle recycling industry. Both these factors makes it vital to quantify the material streams of an EOL ship to calculate cost and income of recycling a ship.

\subsection{Material composition of end-of life ships}

For this study, all the available research papers and technical reports on material quantification of EOL ships were reviewed. Unfortunately unlike the car and aircraft industry, the number is limited (nine only). The very small number of studies available on this subject is attributed to ship recycling yards being sceptical about sharing the information and data. The prevalent scepticism is mainly due to continuous scrutiny of recycling yards by environmental watchdogs. Other stakeholders, such as classification societies and ship recycling consultants are bound by the non-disclosure agreements of the proprietary data. 
The literature review found that the studies used four different methods to quantify material streams of EOL ships. This include interviews of ship recyclers, sampling on a few ships, sampling on the beaches of a few recycling yards, and an input-output method applied at a particular recycling yard based on the approximate historical data of few ships.

While Andersen et al. (1999) aimed to quantify the materials of environmental concerns available on an EOL VLCC ship by sampling; Hiremath et al. (2015) and Sarraf (2010) attempted to quantify waste streams of various ship types on an aggregate level whereas Reddy et al. (2003) attempted to quantify the waste generated by Alang-Sosiya ship breaking yard in Gujarat, India in terms of MT/day by sampling on beach. Although all four authors (Andersen et al., 1999, Hiremath et al., 2015, Reddy et al., 2003, Sarraf, 2010) attempted to quantify only the waste streams while ignoring other material streams such as ferrous, non-ferrous, machinery etc., their studies are unfortunately not comparable due to different approach of research used by them.

The study carried out by Hiremath et al. (2015) is the most accurate of these studies because authors used a relatively large sample set of 241 ships. However, both the type of ships demolished and the materials on board vessels change over time (the first due to economic circumstances and the second due to changes in regulations). For example, International Maritime Organization (IMO) started banning asbestos by means of SOLAS convention in 2002 which was eventually banned totally for use on all installations on all ships in 2011 (LloydsRegister, 2011). This means resampling will need to be done regularly to make sure the values of emission factors remain correct. It was also noted that bilge water was assumed as part of LDT, but as it is operationally generated, it should be part of deadweight tonnage (DWT) (Eyres, 2007). Sarraf (2010) used gross tonnage (GT) to represent the ship size, which is rather impractical as GT is a measure of volume rather than a weight (Eyres, 2007). Also, Sarraf (2010) claim to have had no access to proprietary data of Inventory of Hazardous Materials (IHM) of various ships available with classification societies, making estimation difficult and inaccurate. Lastly, the results obtained by Reddy et al. (2003) are the most inaccurate ones due to calculation discrepancies and unrealistic assumptions such as only source of waste collected at Alang-Sosiya beach are ships and no extrapolation of the amount of waste found in three months to the value for one year, the value was taken as is.

\begin{tabular}{|c|c|c|c|c|c|c|c|c|c|c|}
\hline \multirow[b]{2}{*}{ Material streams } & \multicolumn{3}{|c|}{ (Adak, 2013) } & \multicolumn{2}{|c|}{$\begin{array}{c}\text { (Andersen et al., } \\
\text { 2001) }\end{array}$} & \multirow{2}{*}{\begin{tabular}{|c|}
$\begin{array}{c}\text { Demar } \\
\text { ia, } \\
\text { 2010) }\end{array}$ \\
के \\
के \\
\end{tabular}} & \multicolumn{3}{|c|}{ (Hess et al., 2001) } & \multirow{2}{*}{ 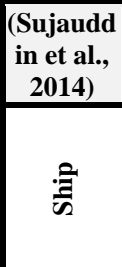 } \\
\hline & 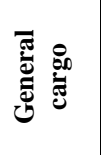 & 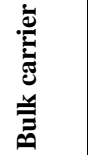 & 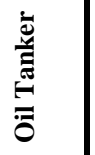 & 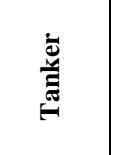 & 离 & & 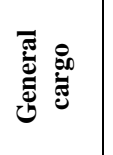 & 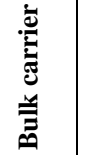 & 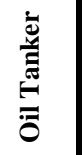 & \\
\hline Ferrous scrap & 64.50 & 68.50 & 76.50 & 74.40 & 63.15 & $75-85$ & $56-70$ & $61-71$ & $72-81$ & 85.00 \\
\hline Re melting scrap & 10.00 & 9.00 & 6.00 & & & 3.00 & 10.00 & $8-10$ & $5-7$ & \\
\hline Cast Iron & 1.75 & 2.00 & 2.50 & & & & $2-5$ & $2-3$ & $2-3$ & \\
\hline Non-ferrous scrap & 0.75 & 1.00 & 1.25 & 0.07 & 0.12 & 1.00 & 1.00 & 1.00 & $1-2$ & 0.40 \\
\hline Machinery & 6.00 & 3.50 & 1.25 & 14.00 & 19.00 & $10-15$ & $4-8$ & $2-5$ & $1-2$ & 8.60 \\
\hline Electrical and electronic equipment & & & & 2.50 & 5.00 & & & & & \\
\hline Minerals & & & & 0.50 & 2.50 & & & & & \\
\hline Plastics & & & & 0.50 & 1.20 & & & & & \\
\hline Liquids, Chemicals and Gases & & & & 2.03 & 1.03 & & & & & \\
\hline Furnace oil and oils & & & & & & 2.00 & & & & \\
\hline Joinery & & & & 5.00 & 6.00 & & & & & \\
\hline Wooden and furniture & & & & & & 2.00 & 5.00 & $1-5$ & $1-2$ & \\
\hline Miscellaneous & 5.00 & 3.00 & 1.50 & 1.00 & 2.00 & & & & & \\
\hline Burning, cutting losses and waste & & & & & & $5-10$ & & & & 6.00 \\
\hline Weight loss & 12.00 & 13.00 & 11.00 & & & & $9-15$ & $10-16$ & $10-12$ & \\
\hline
\end{tabular}

Table 1: Amount of material streams (percentage of LDT) of end-of-life ships as obtained by reviewed studies 
The studies carried out by Adak (2013), Andersen et al. (2001), Demaria (2010), Hess et al. (2001) and Sujauddin et al. (2014) are an attempt to quantify all the material streams of EOL ships using different research ideologies. The results of these studies are compiled in Table 1. While Adak (2013) and Hess et al. (2001) focused on material quantification of three major ship types General cargo, Bulk carrier and Oil tanker, Demaria (2010) and Sujauddin et al. (2014) focused on ships in general. These estimates are on an aggregate level based on the experience of ship recyclers and waste disposal data published by government agencies in India and Bangladesh. They are mere approximations of the quantity of material streams of an EOL ship. Unexplained weight losses of 9\% to 16\% of the weight of the vessel are reported by Adak (2013) and Hess et al. (2001). This weight loss might be due to margins of error and misdeclarations. In India and Pakistan, there have been regular instances of discrepancies in declared import weight and material sold for re-rolling. This include cases where more scrap was reportedly sold than imported (Imaduddin, 2012, Krishna, 2010). The misdeclarations can be for several reasons; the material stream is either escaped to the environment (Sujauddin et al., 2014), is dumped illegally either into the sea or at nearby villages (Demaria, 2010, Upadhyay, 2002), or quite simply done for tax evasion.

The study carried out by Andersen et al. (2001) for classification society DNV is the only one that focused on individual ships Tanker and Bulker to calculate their material composition by sampling on a VLCC ship and using empirical estimations available in the ship design literature (Bertram and Schneekluth, 1998) to calculate the weight of machinery $\left(\mathrm{W}_{\mathrm{m}}\right)$, outfitting $\left(\mathrm{W}_{\mathrm{o}}\right)$ and steel $\left(\mathrm{W}_{\mathrm{s}}\right)$. This is the most detailed and comprehensive of all the studies. Other studies on ship recycling (Koga et al., 2008) have used this data as well. The major drawback of this study is the use of data on $\mathrm{W}_{\mathrm{m}}, \mathrm{W}_{\mathrm{o}}$ and $\mathrm{W}_{\mathrm{s}}$ from the literature make these estimates inaccurate because this data is not up to date and the composition of ships changes over the time.

In conclusion, all of these studies use aggregate data for large groups of ships, none of these studies present a methodology that can be used by recycling yards to determine the amount of various material streams of a specific ship that they are working upon. In this paper, the authors thus present a methodology to quantify the material streams of an EOL ship using the information available from the ship at the time of offering.

\section{Discussion and research methodology}

The methodology developed in this paper is based on the information available to ship recycling yards when they buy an obsolete vessel from the ship owners. In the present scenario, where no international regulation on ship recycling is in place, the ship's stability manual is the only document that is made available by a ship owner to various stakeholders of the ship recycling industry. It contains detailed ship specific information and parameters such as length, breadth, depth, displacement, deadweight and lightweight distribution. Lightweight (LDT) is a measure of ship's weight as built without cargo, bilge water, ballast, fuel oil, stores, spares, crew and its personal effects (Eyres, 2007). It is an important parameter for a recycling yard to estimate the steel weight of the ship for calculating recycling cost and planning the recycling activities while port authorities levy import duty, customs duty and other taxes on an EOL ship per LDT basis.

The stability manual is a legal document that must always be kept on board the vessel. It is created by naval architects to help ship's crew calculate the vessels stability in varying conditions of load to ensure safe vessel operations (Barrass and Derrett, 2011). An important aspect of ship's stability manual is that it must be approved by the classification society with other plan approval documents at the time of building a ship. It must also be updated regularly throughout the ship's lifetime for any changes to vessels' main particulars including lightweight. Moreover, ship's stability manual is required to contain certain mandatory documentation specific to each ship type (DNV, 2011). In general, contents of the stability manual must have sufficient information to enable safe and stable ship operation, it is however not standardised.

Once the Hong Kong convention (HKC) on ship recycling adopted by International Maritime Organization (IMO) in 2009 (IMO, 2009) comes into force, ship owners would be obliged to share the 
Inventory of Hazardous Materials (IHM) along with other ship specific information such as finished drawings of major equipment, general arrangement, engine room arrangement, piping diagrams, capacity plan, shell expansion plan, fire control plan etc. with ship recycling facilities for developing a ship recycling plan (IMO, 2011). The convention is open for accession by any State and it will enter into force whenever its entry into force criteria is fulfilled (IMO, 2015). As major recycling nations having a large number of non-complying yards have a major influence on enforcement of the HKC (Cameron-Dow, 2013), it is expected to take quite some time before it will come into force.

Although ship specific information that would be made available post implementation of the HKC would help better plan the recycling process, it would not allow for a direct calculation of all the material weights. Hence, even if the convention comes into force, a method is still needed to quantify the material streams of an EOL ship. The lightweight distribution presented in the ship's stability manual can be used for this purpose using a two-step methodology explained below.

The lightweight distribution of the case ship, a 2006 built handymax bulk carrier, is composed of four components i.e. machinery components comprising elements M01 to M10, outfitting components comprising elements U01 to U09, steel components comprising elements S01 to S16, and the correction factor comprising element X01. The exact lightweight distribution as given in the stability manual (CarlBro, 2006) of the case ship, arranged by components, is shown in Table 2.

After completing the first step of arranging individual elements of the lightweight distribution of the case ship into four main components machinery, outfitting, steel and correction factor based on the codes $\mathrm{M}, \mathrm{U}, \mathrm{S}$ and $\mathrm{X}$ respectively given in the stability manual, the second and final step is to distribute each of the 36 elements M01 to M10, U01 to U09, S01 to S16 and X01 into various material streams.

\begin{tabular}{|c|c|c|c|c|}
\hline S.no. & Code & Components & Area & Weight (T) \\
\hline 1. & M01 & \multirow{10}{*}{ 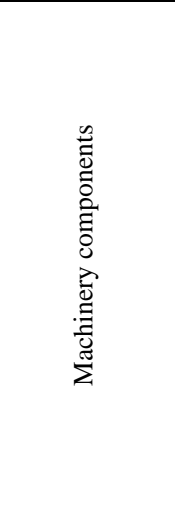 } & Machinery piping & 95.0 \\
\hline 2. & M02 & & Electrical & 25.0 \\
\hline 3. & M03 & & Bridge equipment & 6.0 \\
\hline 4. & M04 & & Tools and Spares & 15.0 \\
\hline 5. & M05 & & Main Engine & 220.0 \\
\hline 6. & M06 & & Shafts & 28.0 \\
\hline 7. & M07 & & Propeller & 17.0 \\
\hline 8. & M08 & & Auxiliary engines & 38.0 \\
\hline 9. & M09 & & Machinery comp & 80.0 \\
\hline 10. & M10 & & Machinery equip & 115.0 \\
\hline 11. & U01 & \multirow{9}{*}{ 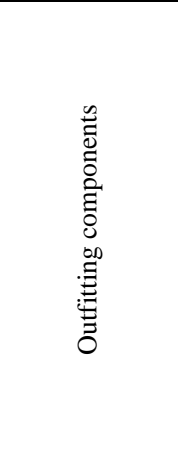 } & Crane 1 & 57.0 \\
\hline 12. & U02 & & Crane 2 & 57.0 \\
\hline 13. & U03 & & Crane 3 & 57.0 \\
\hline 14. & U04 & & Crane 4 & 57.0 \\
\hline 15. & U05 & & Hatches & 880.0 \\
\hline 16. & U06 & & Outfit For & 220.0 \\
\hline 17. & U07 & & Outfit Mid & 200.0 \\
\hline 18. & U08 & & Outfit Aft & 500.0 \\
\hline 19. & U09 & & Paint and Cathodes & 130.0 \\
\hline 20. & S01 & \multirow{4}{*}{ 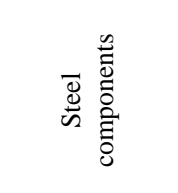 } & Forepeak Fcle & 320.0 \\
\hline 21. & $\mathrm{~S} 02$ & & Bhd CH1-CH2 & 182.0 \\
\hline 22. & $\mathrm{~S} 03$ & & Bhd CH2-CH3 & 198.0 \\
\hline 23. & S04 & & Bhd CH3-CH4 & 198.0 \\
\hline
\end{tabular}


This is the author's post-print version.

Article published by Elsevier in journal 'Resources, Conservation and Recycling' is available at http://www.sciencedirect.com/science/article/pii/S0921344915301452

\begin{tabular}{|c|c|c|c|c|}
\hline 24. & S05 & & Bhd CH4-CH5 & 182.0 \\
\hline 25. & S06 & & Cargo Section & 5600.0 \\
\hline 26. & S07 & & Machinery Section & 1070.0 \\
\hline 27. & S08 & & Casing Funnel & 80.0 \\
\hline 28. & S09 & & Accommodation & 320.0 \\
\hline 29. & $\mathrm{~S} 10$ & & Hatch coaming & 205.0 \\
\hline 30. & $\mathrm{~S} 11$ & & Crane pedestal 1 & 18.0 \\
\hline 31. & $\mathrm{~S} 12$ & & Crane pedestal 2 & 18.0 \\
\hline 32. & $\mathrm{~S} 13$ & & Crane pedestal 3 & 18.0 \\
\hline 33. & S14 & & Crane pedestal 4 & 18.0 \\
\hline 34. & $\mathrm{~S} 15$ & & Deck house Fr. 72 & 12.0 \\
\hline 35. & $\mathrm{~S} 16$ & & Deck house Fr. 144 & 12.0 \\
\hline \multirow[t]{2}{*}{36.} & X01 & $\begin{array}{l}\text { Correction } \\
\text { factor }\end{array}$ & Tol and Marg & -203.9 \\
\hline & & & Total LDT (tonnes) : & 11044.1 \\
\hline
\end{tabular}

Table 2: Lightweight distribution of the case ship as given in its stability manual

The material streams for this distribution are derived from the DNV study (Andersen et al., 2001) as it is the most comprehensive and realistic list of material streams presented by any author in the literature. According to the DNV study, there are a total of nine material streams originating from an EOL ship as shown in Table 3. For easy calculations, the authors of this paper assign each material stream a code starting from W01 to W09. The material stream W07: liquids, chemicals and gases is not a part of ship's LDT because it is usually generated operationally. Hence, it will not play a role in converting the weight elements into material streams. The operationally generated material streams make the final weight of the ship at the end of its life higher than its LDT recorded at the time of building.

\begin{tabular}{|l|l|}
\hline Code & Material Stream \\
\hline W01 & Ferrous scrap \\
\hline W02 & Non-ferrous scrap \\
\hline W03 & Machinery \\
\hline W04 & Electrical and electronic equipment \\
\hline W05 & Minerals \\
\hline W06 & Plastics \\
\hline W07 & Liquids, Chemicals and Gases \\
\hline W08 & Joinery \\
\hline W09 & Miscellaneous \\
\hline
\end{tabular}

Table 3: Material streams of an end-of-life ship

The quantification of material streams using the methodology developed in this paper mainly depends on the weight elements of the lightweight distribution of the ship recorded in its stability manual. Although international rules governing the general contents of the stability manual (DNV, 2011) ensure that the lightweight particulars of a ship are recorded in its stability manual, unfortunately there is no rule standardizing the elements of the lightweight distribution. These elements could be more comprehensive than the elements of the case ship or just a few elements, say steel weight, outfitting weight and machinery weight put together to calculate the final LDT. However, it is very likely that lightweight distribution of every ship would contain detailed enough weight elements similar to that of the case ship due to reasons such as (1) ship building yards usually calculate weight elements in detail using a software having standardized weight elements (2) quantification of weight elements in detail is required by ship building yards to calculate ship construction costs (3) the classification society surveyor might be interested in detailed level of weight elements for inclining experiments and 
approval of stability manual, and (4) it is obligatory for the manual to have sufficient details to enable master to operate the ship in compliance with the stability requirements applicable to the vessel.

\section{Application and results}

The division of each of the 36 weight elements M01 to M10, U01 to U09, S01 to S16 and X01 of the case ship into various material streams W01 to W09 is not a straight forward exercise due to unavailability of the information on what material and component formed an element of weight distribution when the ship was constructed. The division can be done on the basis of logical reasoning and empirical evidences within the ship design literature while the knowledge gaps due to unavailability of data are filled-up using the DNV study. The most plausible division of these elements into material streams is shown in Table 4 based on the following discussion.

\begin{tabular}{|c|c|c|}
\hline S.no. & Elements & Material streams \\
\hline & Machinery components & \\
\hline 1. & M01: Machinery piping & W01, W02 \\
\hline 2. & M02: Electrical & W02, W04 \\
\hline 3. & M03: Bridge equipment & W04 \\
\hline 4. & M04: Tools and Spares & W01 \\
\hline 5. & M05: Main Engine & W03 \\
\hline 6. & M06: Shafts & W01 \\
\hline 7. & M07: Propeller & W02 \\
\hline 8. & M08: Auxiliary engines & W03 \\
\hline 9. & M09: Machinery comp & W01, W05 \\
\hline \multirow[t]{2}{*}{10.} & M10: Machinery equip & W03, W09 \\
\hline & Outfitting components & \\
\hline 11. & U01 - U04: Crane 1 - 4 & W03 \\
\hline 12. & U05: Hatches & W01 \\
\hline 13. & U06: Outfit For & W01, W02, W03, W04, W05, W06, W08, W09 \\
\hline 14. & U07: Outfit Mid & W01, W02, W04, W05, W06, W08, W09 \\
\hline 15. & U08: Outfit Aft & W01, W02, W03, W04, W05, W06, W08, W09 \\
\hline \multirow[t]{2}{*}{16.} & U09: Paint and Cathodes & W02, W09 \\
\hline & Steel components & \\
\hline \multirow[t]{2}{*}{17.} & S01 - S16: Steel hull elements & W01 \\
\hline & Correction factor & \\
\hline 18. & X01: Tol and Marg & W01 \\
\hline
\end{tabular}

Table 4: Division of lightweight distribution elements into material streams

\subsection{Steel components and correction factor}

The elements of steel components S01 to S16 and correction factor X01 forms material stream ferrous scrap (W01). It is realistic to add negative component correction factor: X01 to steel components because the most likely cause of such a correction in ship's LDT would be an error in weight estimation of steel components during the initial phase of ship design cycle. Moreover, steel components are the biggest contributing elements (over 80\%) to the ship's LDT.

\subsection{Machinery components}

The elements of machinery components M03 to M08 can be placed in different material streams without any ambiguity. Bridge equipment (M03) can be placed in material stream electrical and electronic equipment (W04); tools and spares (M04) and shafts (M06) form the material stream ferrous scrap (W01); main engine (M05) and auxiliary engines (M08) form the material stream 
machinery (W03); while propeller (M07) can be placed in material stream non-ferrous scrap (W02) because ship's propeller is usually made of special type of bronze.

\subsection{Outfitting components}

Similarly, the elements of outfitting components U01 to U05 can also be placed in different material streams without any ambiguity. The elements U01 to U04 are cranes forming material stream machinery (W03) while hatches (U05) can be placed in material stream ferrous scrap (W01).

\subsection{Remaining components}

The remaining 8 elements of machinery components and outfitting components M01, M02, M09, M10, and U06 to U09 needs to be divided into two or more than two material streams. Dividing these elements into material streams needs a close examination and understanding of how the ships are designed and constructed.

\subsubsection{Remaining machinery components}

The element M01: machinery piping can be split into two material streams ferrous scrap (W01) and non-ferrous scrap (W02) because piping in the machinery room could be of either steel or copper. The weight of ferrous and non-ferrous machinery piping is not known at the time ship is sold to a recycling yard but it is certainly known when the ship is built. The transmission of this information to the recycling yard is critical in quantifying these material streams of an EOL ship. In this study, based on a personal communication to a leading classification society, Lloyds Register; authors estimated that the total weight of copper (non-ferrous) piping in the machinery room would be no more than 5\% of the total piping. It is verified by the fact that most of the machinery piping is constructed of ferrous material (Murdoch, 2012). Though almost every machinery system piping can be of approved nonferrous material such as copper, aluminium and their alloys, if used within the design rules of classification society (DNVGL, 2015); ferrous material is generally preferred due to economic considerations. The author's experience and (Barrass, 2004) confirms that the use of copper piping within the machinery room of a ship is limited to low temperature steam systems and pneumatic systems. The other smaller systems such as systems for compressed air, sanitary systems, bilge, ballast water, brine, hydraulic lines and tank heating also use copper-nickel alloys (CDA, 2015). Thus, an estimate of maximum 5\% for non-ferrous piping seems realistic.

The element M02: electrical should logically form the material stream electrical and electronic equipment (W04) but due to the missing information on whether electrical cables were considered a part of element M02: electrical or element U06, U07, U08: outfitting during ship construction, it is assumed that the element M02 would split into two material streams; non-ferrous scrap (W02) for copper cables, and electrical and electronic equipment (W04) for the equipment. This is based on the generic information provided by ship design literature (Papanikolaou, 2014) confirming that $50 \%$ to $80 \%$ of the weight of electrical concern the weight of cables. Thus, due to relatively small size of the case ship, element M02 is divided equally into two material streams W02 and W04.

The element M09: machinery comp usually concern the weight of ladders, floor gratings, floor plates, railings, heat and noise insulation in the engine room of a ship (Bertram and Schneekluth, 1998, Papanikolaou, 2014). Such information from the ship design literature confirms the division of element M09 into two material streams i.e. ferrous scrap (W01) for ladders, floor gratings, floor plates, and railings and minerals (W05) for heat and noise insulation. The missing information on the weight of individual components comprising the element M09 is fulfilled by the DNV study on VLCC ship (Andersen et al., 1999) which estimated 7T of heat and noise insulation on a 37500 LDT tanker ship. For the case ship, the element M09 weighing 80T is split into 5T of minerals (W05) and 75T of ferrous scrap (W01). The heat and noise insulation of a ship's engine room mainly depends on its size $\left(\mathrm{m}^{3}\right)$.

The element M10: machinery equip concern all the machines and equipment in the engine room except the ones which are reported individually in the stability manual. In the case ship, weight of main engine and auxiliary engine is reported in elements M05 and M07 respectively. This means the element M10 can be split into material streams machinery (W03) and miscellaneous (W09) accounting 
for level switches, thermometers and batteries. Such items are small in size but large in number. Thus, in this study, due to the missing information on the weight of individual components comprising the element M10, weight of material stream W09 originating from the element M10 is approximately considered 1T. The remaining weight of $114 \mathrm{~T}$ is assigned to material stream W03.

\subsubsection{Remaining outfitting components}

The element U09: paint and cathodes can naturally be split into two material streams i.e. non-ferrous scrap (W02) accounting for the weight of cathodes and miscellaneous (W09) accounting for the weight of paint. The information on the individual weights of paint and cathodes is not available when a recycling yard purchases a ship for recycling but it is certainly known to the yard building the ship. The estimations made by DNV for the VLCC ship (Andersen et al., 1999) reveals that the combined weight of paint and cathodes comprises of $58 \%$ of cathode weight and $42 \%$ of paint weight. The weight of the paint is converted from litres to tonnes assuming the density of paint as $1.2 \mathrm{~g} / \mathrm{cu} \mathrm{cm}$. On board ships, different varieties of paints are used (Almeida et al., 2007) having densities ranging from 0.9 to $1.5 \mathrm{~g} / \mathrm{cu} \mathrm{cm}$ (CMP, 2015). Using the above division, cathode weight of the case ship is estimated to be 76T while the weight of the paint is estimated at 54T forming the material streams W02 and W09 respectively. The weight of cathodes measured at the end of ship's life depends on when the ship was last dry docked for renewal of cathodes and other repairs, as this material is 'sacrificed' to prevent rusting of ship's hull (Bohnes and Richter, 1997).

The elements U06, U07 and U08 represent the weight of outfitting forward, middle and aft of ship respectively. The outfitting on a ship usually consists of various items made of different materials. Shipyards use differing schemes to denote which items are considered outfitting. The ship design literature can provide some insight regarding this topic. For example, Bertram and Schneekluth (1998) (pg. 169) divided outfitting into four major groups hatchway covers, loading equipment, accommodation, miscellaneous. Similarly, Papanikolaou (2014) (pg. 215) divided outfitting into eight groups comprising various items. Every ship yard has their own criteria to include items within the outfitting weight group. At recycling stage, it is impossible to segregate outfitting elements U06, U07, and U08 into the material streams without having the information from the ship building yard.

In this study, outfitting elements are considered to contain all the material streams from W01 to W09 except W07: liquids, chemicals and gases which is operationally generated and is not the part of ship's lightweight. Another exception is omission of material stream machinery (W03) originating from the element outfit mid (U07) because it is unlikely that a bulk carrier would have machinery installed at its mid area, when cranes are part of different elements (U01-U04). The outfitting elements of the lightweight distribution of the case ship are distributed into various material streams using the following logical assumptions.

The material stream ferrous scrap (W01) generated from the outfitting elements mainly comprise of stairs, ladders, railings, pipes, anchor and chain (Bertram and Schneekluth, 1998, Papanikolaou, 2014). Similar subdivision from machinery component M09 resulted in 75T of ferrous scrap stream. It is assumed that the part of the ship other than machinery space would have similar weight for stairs, ladders, railings and pipe. Thus, $75 \mathrm{~T}$ is subdivided into equal parts of $25 \mathrm{~T}$ each for the outfitting forward, mid and aft respectively. The anchor and chain weight is estimated on the basis of design rules by the International Association of Classification Societies, IACS (IACS, 2014). A weight of $30 \mathrm{~T}$ attributed to the weight of the anchor and chain is thus added to outfitting forward, making a total of $55 \mathrm{~T}$ for ferrous scrap (W01) originating from element U06: outfit for.

The material stream non-ferrous scrap (W02) generated from the outfitting elements is estimated to be a total of 6T based on the following discussion. Within the outfitting part (elements U06 to U08), nonferrous material such as copper and brass are mainly used for sidelights, handrails, sounding pipe caps, fire main valves, sprinkler system and heads of vent and overflow pipes on weather deck (CDA, 2015) while aluminium and its alloys are fitted in navigation spaces because of their non-magnetic characteristics (Barrass, 2004). Weight of such outfitting is estimated to be very small amount at about $2 \mathrm{~T}$ each for outfitting forward (U06), mid (U07) and aft (U08). Further data is needed to verify these estimates. 
The material stream machinery (W03) generated from the outfitting elements consist of the windlasses, mooring winches and steering gear (Bertram and Schneekluth, 1998, Papanikolaou, 2014). Generally, there is no machinery located at the midship which means material stream machinery (W03) does not originate from the element U07: outfit mid. The total weight of all the equipment aft and forward is estimated at $60 \mathrm{~T}$ and $30 \mathrm{~T}$ respectively by author's experience and industry experts' opinion.

In order to quantify remaining five material streams W04, W05, W06, W08, W09 originating from elements U06, U07, U08 authors of this paper assumed that the percentages estimated by DNV study (Andersen et al., 2001) holds true for the material streams minerals (W05) and plastics (W06) because DNV study focussed on sampling of materials of environmental concerns such as asbestos and glass wool in minerals category and PVC in plastics category (Andersen et al., 1999). The quantification of material streams W04, W08 and W09 is carried out by dividing the remaining non-estimated weight of outfitting elements proportionally. The proportion numbers for material streams are used from the DNV study (Andersen et al., 2001) because they are the best available estimates in the literature.

In this methodology, liquids such as lube oil and fresh water contained within various machines are not quantified separately. They are considered as a part of machinery weight. The final distribution of the weight elements of the case ship into various material streams is compiled in Table 5 and its material composition as calculated using the proposed methodology is shown by Figure 1.

\begin{tabular}{|c|c|c|c|c|c|c|c|c|c|c|}
\hline S. no. & Stability manual element & W01: Fe & $\begin{array}{l}\text { W02: } \\
\text { Non-Fe }\end{array}$ & $\begin{array}{l}\text { W03: } \\
\text { M/C }\end{array}$ & $\begin{array}{l}\text { W04: } \\
\text { E\&E }\end{array}$ & $\begin{array}{l}\text { W05: } \\
\text { Minerals }\end{array}$ & $\begin{array}{l}\text { W06: } \\
\text { Plastics }\end{array}$ & $\begin{array}{l}\text { W08: } \\
\text { Joinery }\end{array}$ & $\begin{array}{l}\text { W09: } \\
\text { Misc. }\end{array}$ & $\begin{array}{c}\text { Total } \\
\text { (Tonnes) }\end{array}$ \\
\hline 1 & M01: Machinery piping & 90.0 & 5.0 & & & & & & & 95.0 \\
\hline 2 & M02: Electrical & & 12.5 & & 12.5 & & & & & 25.0 \\
\hline 3 & M03: Bridge equipment & & & & 6.0 & & & & & 6.0 \\
\hline 4 & M04: Tools and Spares & 15.0 & & & & & & & & 15.0 \\
\hline 5 & M05: Main Engine & & & 220.0 & & & & & & 220.0 \\
\hline 6 & M06: Shafts & 28.0 & & & & & & & & 28.0 \\
\hline 7 & M07: Propeller & & 17.0 & & & & & & & 17.0 \\
\hline 8 & M08: Auxiliary engines & & & 38.0 & & & & & & 38.0 \\
\hline 9 & M09: Machinery comp & 75.0 & & & & 5.0 & & & & 80.0 \\
\hline 10 & M10: Machinery equip & & & 114.0 & & & & & 1.0 & 115.0 \\
\hline 11 & U01 - U04: Crane 1-4 & & & 228.0 & & & & & & 228.0 \\
\hline 12 & U05: Hatches & 880.0 & & & & & & & & 880.0 \\
\hline 13 & U06: Outfit For & 55.0 & 2.0 & 30.0 & 13.6 & 66.0 & 31.7 & 16.3 & 5.4 & 220.0 \\
\hline 14 & U07: Outfit Mid & 25.0 & 2.0 & & 32.4 & 60.0 & 28.8 & 38.8 & 12.9 & 200.0 \\
\hline 15 & U08: Outfit Aft & 25.0 & 2.0 & 60.0 & 73.4 & 150.1 & 72.0 & 88.1 & 29.4 & 500.0 \\
\hline 16 & U09: Paint and Cathodes & & 76.0 & & & & & & 54.0 & 130.0 \\
\hline 17 & S01 - S16: Steel hull elements & 8451.0 & & & & & & & & 8451.0 \\
\hline 18 & X01: Tol and Marg & -203.9 & & & & & & & & -203.9 \\
\hline & Total: & 9440.1 & 116.5 & 690.0 & 137.9 & 281.1 & 132.5 & 143.2 & 102.7 & 11044.1 \\
\hline & Percentage: & 85.48 & 1.05 & 6.25 & 1.25 & 2.55 & 1.20 & 1.30 & 0.93 & 100.00 \\
\hline
\end{tabular}

Table 5: Distribution of weight elements of the case ship into material streams

The material composition shown in Figure 1 is based on the lightweight distribution of the case ship as recorded in its stability manual. However, final material composition may differ from this because of the fact that the weight of an EOL ship is usually more than its LDT due to the unaccounted weight added during its lifetime. This extra weight includes operationally generated waste, stores, spares, paint on ship structure and remaining quantity of liquids such as fuel oil, lube oil, sludge, sewage etc. Generally, ship's LDT is updated by classification society in case of major structural modification or machinery retrofitting. In most cases, material stream liquids, chemicals, and gases (W07) would be added to the final material composition. The quantity of this material stream depends on the remaining on board (ROB) figures recorded when an EOL ship reaches the recycling yard. 


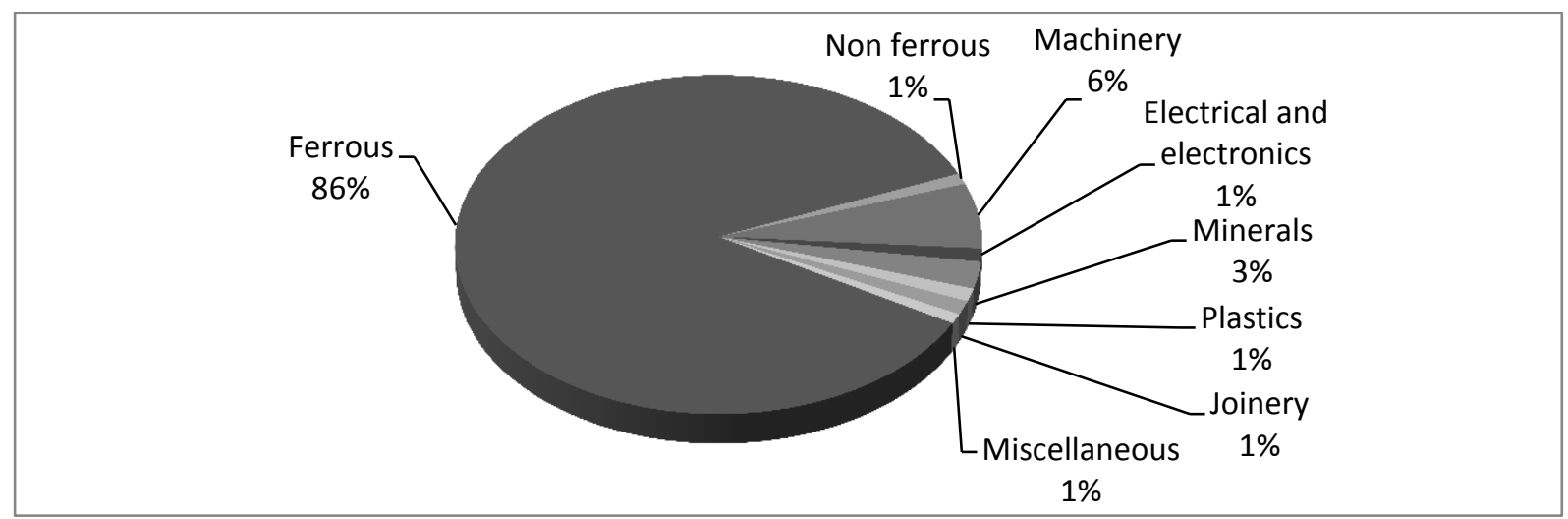

Figure 1: Material composition of the 11000 LDT handymax bulk carrier based on its stability manual

\section{Analysis and recommendation}

A methodology for the material quantification of an EOL ship using its stability manual is presented in this paper. This methodology is unique in nature because it uses the information that is readily available to a ship recycling yard. It can not only be used by ship recycling yards to quantify the material streams of an EOL ship with a greater degree of accuracy but also be applied for further research in this field. The accurately quantified material streams can help recycling yards planning the recycling process and perhaps in a later stage the equipment utilisation can also be improved, further reducing the costs of the yard. Furthermore, the uncertainty in calculating the offer price can be reduced.

A drawback of this methodology is that it relies heavily on the level of detail of the lightweight distribution recorded in the ship's stability manual. Since the number of weight elements of the lightweight distribution is not standardized by any international rule, their level of detail can differ from ship to ship. The authors of this paper recommend that there should be a standardized format of the weight elements of the lightweight distribution of the ship. The number of weight elements should be comprehensive enough to reveal the material composition of the ship.

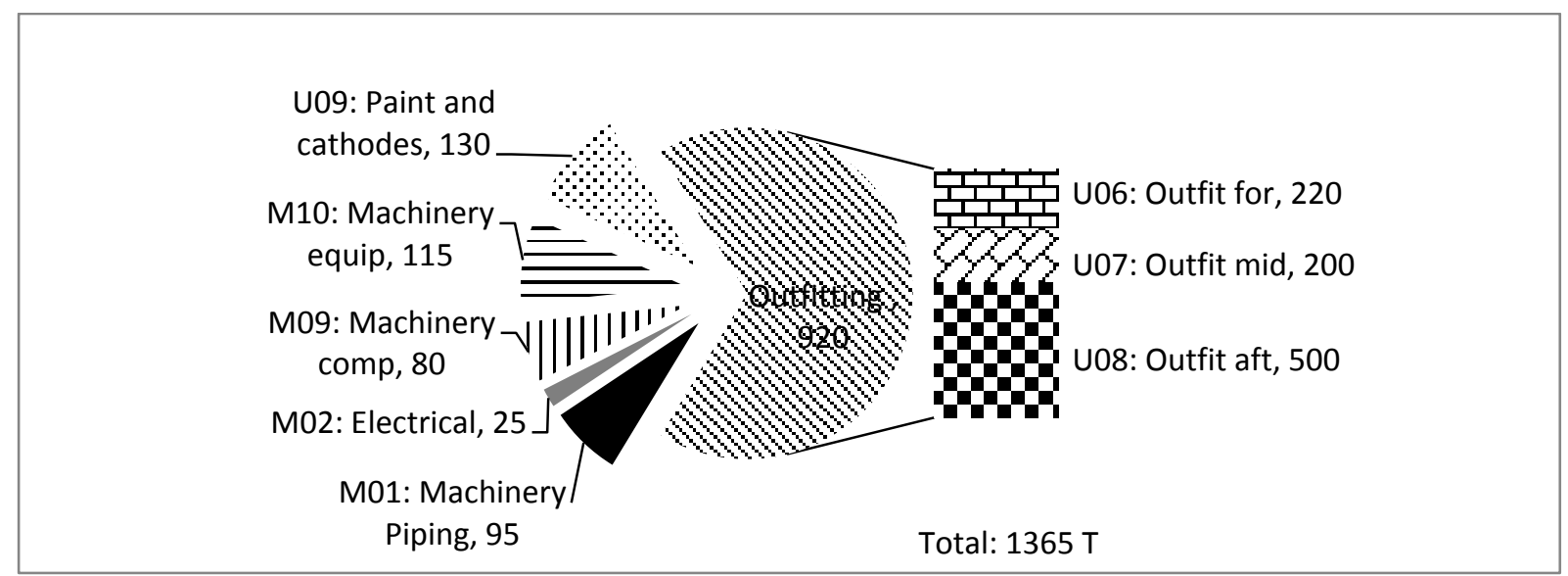

Figure 2: Weight $(T)$ of elements with missing information

The developed methodology is able to predict up to 88 percent (9679 tonnes) of the material quantity of the case ship without any ambiguity. The approximation is done only for the 12 percent of LDT (1365 tonnes) owing to the missing information regarding the individual components forming elements M01, M02, M09, M10, and U06 to U09 of the lightweight distribution (Figure 2). The information required for more accurate material quantification include the breakdown of M01 into weight of ferrous and non-ferrous piping, M02 into weight of cables and electrical equipment, M09 into the weight of individual components such as heat and noise insulation, and ferrous material 
stream formed by railings, stairs, floor gratings, floor plates etc., M10 into the weight of individual equipment such as level switches, thermometers and batteries, U06 to U08 into the weight of individual components and U09 into the weight of paint and cathodes separately. The outfitting elements form the highest percentage $(67 \%)$ of weight of the components with missing information.

Most of the information which is required to estimate the ship's material composition to a greater degree of accuracy is available when the ship is constructed, yet it is not passed on to the ship recycling yard at the end of ship's economic life. It is thus recommended that the detailed work breakdown structure (WBS) having weights and centres calculation used during ship design and construction must be preserved and kept on board. It must be transferred from the shipyard to the recycling yard through the ship owners over the lifetime of a ship for further enhancement of the accuracy of the developed methodology. The availability of detailed WBS and stability manuals of EOL ships would also enhance the prospects of data collection related to material composition of EOL ships improving the current scenario where researchers face hurdles in collecting such data. The sharing of such information with all the stakeholders can go a long way in developing the ship recycling industry into safe and environmentally friendly industry.

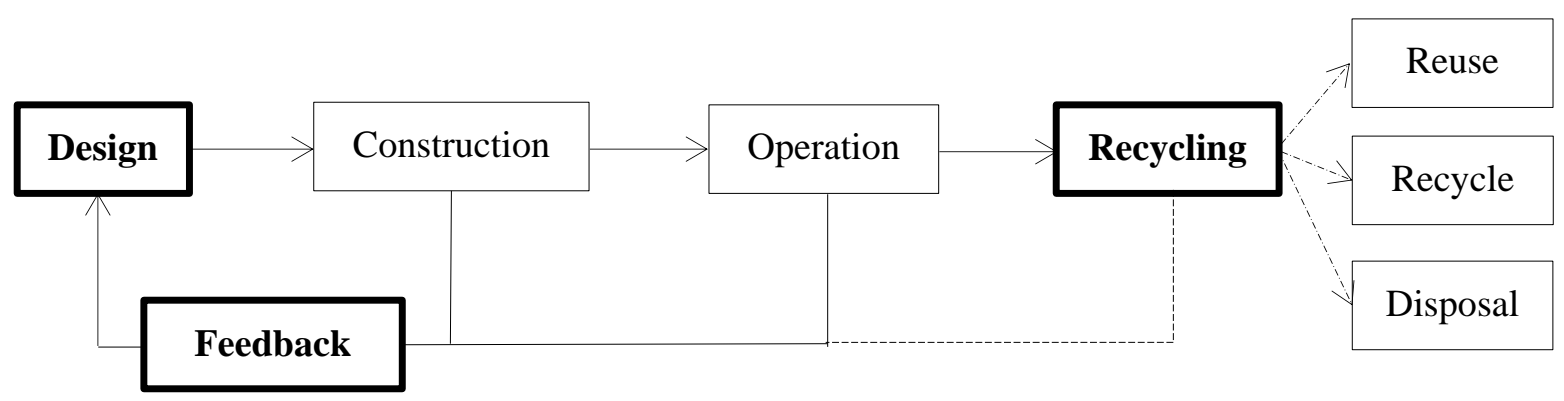

Figure 3: Feedback to design phase of the ship's life cycle.

The aforementioned recommendations are feedback from the recycling phase to the design phase of a ship's lifecycle. Such a feedback generated as a result of analysis of ship recycling process can improve ship designs to achieve safe and environmentally sound ship recycling (Jain et al., 2014) as depicted by Figure 3. The collaboration between design of products and waste management is investigated by Ordoñez and Rahe (2013) and Ardente et al. (2015) while van Schaik and Reuter (2004), Ferrão and Amaral (2006), Mayyas et al. (2012) and Tian and Chen (2014) investigated the design for dismantling (DfD) concept for EOL vehicles. The application of DfD concept on ships is studied by Alkaner et al. (2006), McKenna et al. (2012), Sivaprasad and Nandakumar (2013) and Jain et al. (2014). All of them have emphasized the importance of designing a ship in such a way that it is safe and environmentally friendly to recycle by establishing a link between the recycling phase and the design phase of the ship's life cycle. This link in the form of feedback from the recycling phase to the design phase ensures that ship's recycling phase is analysed and improved and at the same time ship designs are also improved based on the feedback from the recycling phase to achieve safe and environmentally sound ship recycling.

\section{Conclusion}

In the absence of a scientific tool to quantify material streams of EOL ships, recycling yards resort to use expert opinion and their own judgement based on the experience to quantify material streams of an obsolete vessel they are working upon. This estimation is, to some extent, also the basis of the price offered to a ship owner and for the planning of processes on a recycling yard.

An extensive literature survey of the subject found no methodology that can be used to quantify the material streams of an individual ship. Upon investigation, it was determined that the stability manual of an EOL ship can be used to determine the material composition of the ship with a much more accuracy than determined using the present quantification methods. 
Although, ship's stability manual does not contain all the information required for an accurate estimation of material streams; it was proved in this paper, by quantifying material streams of a handymax bulk carrier with an $88 \%$ accuracy, that stability manuals can be used to quantify material streams of EOL ships using the developed methodology. The lack of standardization for the number of weight elements of the lightweight distribution given in the stability manual is a pitfall for this methodology. It can be overcome by making it mandatory for ship building yards to provide a detailed breakdown of weight elements in the lightweight distribution of a ship. The estimation of weight elements at a fairly detailed level is anyway carried out by ship building yards in order to calculate costs and other ship stability parameters accurately. It is just the matter of reporting it in the ship's official documents such as stability manual.

The use of stability manual means developed methodology uses the information from the design stage of the ship's lifecycle. The missing link between the design stage and the recycling stage of the ship's lifecycle for an accurate quantification of material streams is the detailed WBS classification system used during the ship construction. The ship recycling yard can use ship's stability manual and detailed WBS classification system not only to determine ship's material composition but also to improve resource allocation and waste management. Moreover, storage capacity of the recycling yard and the activities of the ship recycling process can be planned using MFA based on the quantified material streams resulting in a cost effective, safe and environmentally sound ship recycling.

In this paper, authors applied the proposed methodology on a 11000 LDT handymax bulk carrier to estimate its material composition using the stability manual. It is a test case which proves that working with the ship building yards can further validate this methodology by applying it on different types of new build ships using their stability manuals and WBS information. This can result in a standardized format of the weight elements of the lightweight distribution of ships helping the recycling yards to accurately determine the material composition of every EOL ship they are working upon.

\section{Acknowledgements}

The authors of this paper would like to acknowledge the support of Gieskes Strijbis Fonds for funding this research project on Green Ship Recycling which is performed by the consortium led by Delft University of Technology, The Netherlands and Tianjin University, China along with industrial partners Sea2Cradle B.V., International Ship Recycling Association (ISRA) and Lloyds Register.

\section{References}

ADAK, S. 2013. EIA and EMP for ship recycling facility near Mundra west port in Kachchh district Gujarat. India: MECON Limited.

ALKANER, S., DAS, P. K., SMITH, D. L. \& DILOK, P. 2006. Comparative Analysis of Ship Production and Ship Dismantling. International Conference on Dismantling of Obsolete Vessels. Glasgow, UK.

ALMEIDA, E., DIAMANTINO, T. C. \& DE SOUSA, O. 2007. Marine paints: The particular case of antifouling paints. Progress in Organic Coatings, 59, 2-20.

ANDERSEN, A. B., ENDRESEN, Ø., HALL, S., JOSE, P., KATTAN, R., ORRICK, P., RYDOCK, A. \& SVERUD, T. 2001. Technological and Economic Feasibility Study of Ship Scrapping in Europe. Report No. 2000-3527. Hovik, Norway: DNV.

ANDERSEN, A. B., RØSTAD, A. \& BJØRNBOM, E. 1999. Decommissioning of ships environmental protection and ship demolition practices. Report No. 99-3065. Hovik, Norway: DNV.

ARDENTE, F., CALERO PASTOR, M., MATHIEUX, F. \& TALENS PEIRÓ, L. 2015. Analysis of end-of-life treatments of commercial refrigerating appliances: Bridging product and waste policies. Resources, Conservation and Recycling, 101, 42-52.

ARENA, U. \& DI GREGORIO, F. 2014. A waste management planning based on substance flow analysis. Resources, Conservation and Recycling, 85, 54-66.

BARRASS, B. \& DERRETT, C. D. 2011. Ship stability for masters and mates, Butterworth-Heinemann. 
BARRASS, C. B. 2004. Ship design and performance for masters and mates, Amsterdam, Elsevier Butterworth-Heinemann.

BERTRAM, V. \& SCHNEEKLUTH, H. 1998. Ship design for efficiency and economy, ButterworthHeinemann.

BINDER, C. R. \& MOSLER, H.-J. 2007. Waste-resource flows of short-lived goods in households of Santiago de Cuba. Resources, Conservation and Recycling, 51, 265-283.

BOHNES, H. \& RICHTER, B. 1997. Cathodic Protection of Ships. Handbook of Cathodic Corrosion Protection.

BRUNNER, P. \& RECHBERGER, H. 2004. Practical handbook of material flow analysis, New York, Lewis Publisher.

CAMERON-DOW, L.-L. 2013. Challenges Posed by the Entry into Force Requirements of the Hong Kong Convention: Desperately Seeking a White Rabbit to Lead us into Wonderland. In: BELLEFONTAINE, N., OLCER, A. \& HILDERBRAND, L. (eds.) International Conference on Ship Recycling. World Maritime University, Malmo, Sweden: WMU Publications.

CARLBRO. 2006. Stability Information Manual [Online]. Available: http://bit.ly/1Yrvs7E [Accessed 30.07.2015.

CDA. 2015. Copper-Nickel Alloys in Shipbuilding and Repair [Online]. Copper Development Association Inc. Available: http://bit.ly/1NNbJl6 [Accessed 30.07.2015.

CMP. 2015. Data Sheets [Online]. Available: http://bit.ly/1YrvAEO [Accessed 30.07.2015.

CRANG, M., HUGHES, A., GREGSON, N., NORRIS, L. \& AHAMED, F. 2013. Rethinking governance and value in commodity chains through global recycling networks. Transactions of the institute of british geographers, 38, 12-24.

DE BRITO, M. P., VAN DER LAAN, E. \& IRION, B. D. 2007. Extended producer responsibility in the aviation sector. ERIM Report Series Reference No. ERS-2007-025-LIS.

DEMARIA, F. 2010. Shipbreaking at Alang-Sosiya (India): an ecological distribution conflict. Ecological Economics, 70, 250-260.

DNV 2011. Stability documentation for approval. Classification notes no. 20.1. Norway: DNV.

DNVGL 2015. Rules for Classification and Construction: Ship Technology. Part 1: Seagoing Ships, Chapter 2: Machinery Installations, Section 11: Piping Systems, Valves and Pumps. Hamburg: DNVGL SE.

EYRES, D. J. 2007. Ship construction, Oxford, Butterworth-Heinemann.

FERRÃO, P. \& AMARAL, J. 2006. Design for recycling in the automobile industry: New approaches and new tools. Journal of Engineering Design, 17, 447-462.

FERRÃO, P., NAZARETH, P. \& AMARAL, J. 2006. Strategies for meeting EU end-of-life vehicle reuse/recovery targets. Journal of Industrial Ecology, 10, 77-93.

GERRARD, J. \& KANDLIKAR, M. 2007. Is European end-of-life vehicle legislation living up to expectations? Assessing the impact of the ELV Directive on 'green' innovation and vehicle recovery. Journal of Cleaner Production, 15, 17-27.

GREGSON, N., CRANG, M., AHAMED, F. U., AKTER, N., FERDOUS, R., FOISAL, S. \& HUDSON, R. 2012. Territorial Agglomeration and Industrial Symbiosis: Sitakunda - Bhatiary, Bangladesh, as a Secondary Processing Complex. Economic Geography, 88, 37-58.

HESS, R. W., RUSHWORTH, D., HYNES, M. V. \& PETERS, J. E. 2001. Disposal options for ships. DTIC Document.

HIREMATH, A. M., TILWANKAR, A. K. \& ASOLEKAR, S. R. 2015. Significant steps in ship recycling vis-avis wastes generated in a cluster of yards in Alang: a case study. Journal of Cleaner Production, 87, 520-532.

HUANG, C.-L., VAUSE, J., MA, H.-W. \& YU, C.-P. 2012. Using material/substance flow analysis to support sustainable development assessment: A literature review and outlook. Resources, Conservation and Recycling, 68, 104-116.

IACS 2014. Requirements concerning mooring, anchoring and towing. In: IACS (ed.). 
IMADUDDIN. 2012. Ship-breaking and steel sectors: DGI \& IIR all set to check tax evasion [Online]. Business Recorder. Available: http://bit.ly/1PLVFfv [Accessed 23.11.2015.

IMO 2009. Hong Kong International Convention for the Safe and Environmentally Sound Recycling of Ships, 2009. International Conference on the Safe and Environmentally Sound Recycling of Ships. Hong Kong: IMO.

IMO 2011. 2011 Guidelines for the development of the ship recycling plan. In: IMO (ed.) Annex 2, Resolution MEPC.196(62).

IMO. 2015. Recycling of ships [Online]. Available: http://bit.ly/1XbPCWO [Accessed 30.07.2015.

JAIN, K. P., PRUYN, J. F. J. \& HOPMAN, J. J. 2014. Influence of ship design on ship recycling. Maritime Technology and Engineering. CRC Press.

JEFF, S. \& GREGORY, A. 2001. Management of end-of life vehicles (ELVs) in the US. A report of the center for sustainable systems no. CSSO1-01.

KANARI, N., PINEAU, J. L. \& SHALLARI, S. 2003. End-of-Life Vehicle Recycling in the European Union. JOM, 55, 15-19.

KOGA, T., MATSUBARA, M. \& AOYAMA, K. Disassembling System of Large Scaled Structure Considering Safety, Environmental Impact, and Economic Efficiency. ASME 2008 International Design Engineering Technical Conferences and Computers and Information in Engineering Conference, 2008. American Society of Mechanical Engineers, 279-288.

KRISHNA, G. 2010. Shipbreakers face raid by Economic Intelligence Wing [Online]. IMO WATCH. Available: http://bit.ly/1PXOukK [Accessed 23.11.2015.

LLOYDSREGISTER 2011. Classification news. Statutory alert Asbestos on board ships - contravention of SOLAS requirements London.

MAT SAMAN, M. Z. \& BLOUNT, G. N. 2006. End of life vehicles recovery: process description, its impact and direction of research. Jurnal Mekanikal, 40-52.

MATHIEUX, F. \& BRISSAUD, D. 2010. End-of-life product-specific material flow analysis. Application to aluminum coming from end-of-life commercial vehicles in Europe. Resources, Conservation and Recycling, 55, 92-105.

MAYYAS, A., QATTAWI, A., OMAR, M. \& SHAN, D. 2012. Design for sustainability in automotive industry: A comprehensive review. Renewable and Sustainable Energy Reviews, 16, 18451862.

MCKENNA, S. A., KURT, R. E. \& TURAN, O. 2012. A methodology for a 'design for ship recycling'. Royal Institution of Naval Architects - International Conference on the Environmentally Friendly Ship. London: RINA.

MISRA, P. \& MUKHERJEE, A. 2009. Ship Recycling: A Handbook for Mariners, New Delhi, Narosa Publishing House.

MURDOCH, E. 2012. The Master's Guide to Ships' Piping. London: Standard Club.

ORDOÑEZ, I. \& RAHE, U. 2013. Collaboration between design and waste management: Can it help close the material loop? Resources, Conservation and Recycling, 72, 108-117.

PAPANIKOLAOU, A. 2014. Ship Design: Methodologies of Preliminary Design, Springer.

RAHMAN, S. M. \& MAYER, A. L. 2015. How social ties influence metal resource flows in the Bangladesh ship recycling industry. Resources, Conservation and Recycling, 104, Part A, 254264 .

REDDY, M. S., BASHA, S., KUMAR, V. S., JOSHI, H. \& GHOSH, P. 2003. Quantification and classification of ship scraping waste at Alang-Sosiya, India. Marine pollution bulletin, 46, 1609-1614.

RIBEIRO, J. S. \& GOMES, J. D. O. 2015. Proposed Framework for End-of-life Aircraft Recycling. Procedia CIRP, 26, 311-316.

SAKAI, S.-I., YOSHIDA, H., HIRATSUKA, J., VANDECASTEELE, C., KOHLMEYER, R., ROTTER, V., PASSARINI, F., SANTINI, A., PEELER, M., LI, J., OH, G.-J., CHI, N., BASTIAN, L., MOORE, S., KAJIWARA, N., TAKIGAMI, H., ITAI, T., TAKAHASHI, S., TANABE, S., TOMODA, K., HIRAKAWA, T., HIRAI, Y., ASARI, M. \& YANO, J. 2014. An international comparative study of end-of-life vehicle (ELV) recycling systems. Journal of Material Cycles and Waste Management, 16, 1-20. 
SARRAF, M. 2010. The ship breaking and recycling industry in Bangladesh and Pakistan. Washington, D.C.: World Bank.

SIVAPRASAD, K. \& NANDAKUMAR, C. G. 2013. Design for ship recycling. Ships and Offshore Structures, 8, 214-223.

STOPFORD, M. 2009. Maritime Economics 3e, Routledge.

SUJAUDDIN, M., KOIDE, R., KOMATSU, T., HOSSAIN, M. M., TOKORO, C. \& MURAKAMI, S. 2014. Characterization of ship breaking industry in Bangladesh. Journal of Material Cycles and Waste Management, 17, 72-83.

SUJAUDDIN, M., KOIDE, R., MOHAMMED MOSHARRAF, H. \& MURAKAMI, S. Material flow analysis on ship breaking and recycling industry in Bangladesh. The 10th International Conference on EcoBalance, Yokohama, Japan, 2012.

TIAN, J. \& CHEN, M. 2014. Sustainable design for automotive products: Dismantling and recycling of end-of-life vehicles. Waste Management, 34, 458-467.

UPADHYAY, G. B. 2002. The problems and prospects of ship breaking industry in India with reference to Alang ship breaking yard. PhD, Bhavnagar University.

VAN HEERDEN, D.-J. \& CURRAN, R. 2010. Aircraft Disposal and Recycling. Encyclopedia of Aerospace Engineering. John Wiley \& Sons, Ltd.

VAN SCHAIK, A. \& REUTER, M. A. 2004. The optimization of end-of-life vehicle recycling in the european union. JOM, 56, 39-43.

VERMEULEN, I., VAN CANEGHEM, J., BLOCK, C., BAEYENS, J. \& VANDECASTEELE, C. 2011. Automotive shredder residue (ASR): Reviewing its production from end-of-life vehicles (ELVs) and its recycling, energy or chemicals' valorisation. Journal of Hazardous Materials, 190, 8-27. 